\title{
STANDART DOKUMENTASI ASUHAN KEPERAWATAN
}

\author{
JIHAN ASYLA
}

\author{
jihanasyla20@gmail.com
}

\begin{abstract}
ABSTRAK
Asuhan keperawatan merupakan hal sangat sangat penting bagi seorang profesi keperawatan. Kemampuan seorang perawat memberikan pelayanan yang baik serta kemudian dapat secara efektif mengkomunikasikan tentang perawatan pasien tergantung pada seberapa baik kualitas informasi yang diberikan serta dokumentasi yang disediakan Adanya standar dokumentasi keperawatan bertujuan untuk memberikan pernyataan tentang kualitas dan kuantitas dokumentasi yang telah diberikan dan dijadikan bahan pertimbangan untuk memberikan asuhan selanjutnya, baik untuk memperkuat pola pencatatan dan sebagai petunjuk atau pedoman dalam tindakan keperawatan. Metode yang digunakan dalam kajian ini adalah metode pengumpulan data Adapun data yang digunakan pada kajian ini adalah bersumber dari data yang didapatkan dengan menggunakan Google Scholar, scopus, ebook, dan dari beberapa buku keperawatan Rumah sakit di Indonesia sudah banyak menerapkan sistem dokumentasi pada setiap tindakan yang dilakukan kepada pasien baik tindakan yang dilakukan oleh perawat maupun tindakan yang dilakukan oleh tenaga kesehatan lain
\end{abstract}

Kata kunci : keperawatan, tenaga,tindakan 


\section{Latar Belakang}

Asuhan keperawatan merupakan hal sangat sangat penting bagi seorang profesi keperawatan. Kemampuan seorang perawat memberikan pelayanan yang baik serta kemudian dapat secara efektif mengkomunikasikan tentang perawatan pasien tergantung pada seberapa baik kualitas informasi yang diberikan serta dokumentasi yang disediakan untuk dimanfaatkan oleh semua profesional kesehatan dan antar bidang pelayanan kesehatan oleh sebab itu kita harus mengetahui bagimana standart dokumentasi keperawatan tersebut, yang dimana dokumentasi keperawatan merupakan aspek yang sangat penting dal am praktik keperawatan, menggambarkan catatan kesehatan klien dan dijadikan al at komunikasi dengan tenaga kesehatan lainnya, sebagimana yang kita ketahui bahwa perawat mempunyai waktu operan dari pagi,siang dan malam jika dokumentasi yang dituliskan sal ah atau tidak benar maka komunikasi yang diterimapun salah dan akan berdampak buruk bagi kemajuan kesehatan klien.

Adanya stan dar dokumentasi keperawatan bertujuan untuk memberikan pernyataan

\section{Tujuan}

tentang kualitas dan kuantitas dokumentasi yang telah diberikan dan dij adikan bahan pertimbangan untuk memberikan asuhan selanjutnya,baik untuk memperkuat pola pencatatan dan sebagai petunjuk atau pedoman dal am tindakan keperawatan. Perawat memerlukan standar dokumentasi sebagai petunjuk dan arah agar tidak teijadi penyimpangan dal am melakukan pencatatan dokumentasi dan standart dokumentasi sangat penting dalam penyusunan dokumentasi asuhan keperawatan agar tidak teijadi kesalahan dalam pemberian informasi kemajuan kesehatan klien kepada petugas kesehatan lainnya.

\section{Metode}

Metode yang digunakan dalam kajian ini adalah metode pengumpulan data Adapun data yang digunakan pada kajian ini adalah bersumber dari data yang didapatkan dengan menggunakan Google Scholar, scopus, ebook, dan dari beberapa buku keperawatan 


\section{Hasil}

Rumah sakit di Indonesia sudah banyak menerapkan si stem dokumentasi pada setiap tindakan yang dilakukan kepada pasien baik tindakan yang dilakukan oleh perawat maupun tindakan yang dilakukan oleh tenaga kesehatan lain,seperti dokter, ahli gizi dan lain sebagainya berdasarkan hasil kolaborasi antar tenaga kesehatan mengenai keperawatan yang akan diberikan kepada pasien guna mencapai kejahteraan pasien di rumah sakit.

\section{Pembahasan}

Dokumentasi keperawatan merupakan aspek yang sangat penting dalam praktik keperawatan, menggambarkan catatan kesehatan klien dan dijadikan al at komunikasi dengan tenaga kesehatan lainnya.dokumentasi terdapat dalam berupa kertas, elektronik, audio maupun visual dokumentasi tersebut dapat digunakan untuk memantau kemajuan klien serta dapat dijadikan al at komunikasi dengan tenaga kesehatan lainnya. Hal ini juga dapat mmenggambarkan perawatan apa telah yang diberikan kepada klien.
Standar dokumentasi adalah pernyataan tentang kualitas dan kuantitas dokumentasi dipertimbangkan secara baik untuk memperkuat pola pencatatan dan sebagai petunjuk atau pedoman pendokumentasian dalam tindakan keperawatan. Perawat memerlukan standar dokumentasi sebagai petunjuk dan arah agar tidak teijadi penyimpangan dan melakukan teknik pencatatan dengan benar.(Yustiana \& Abdul,2016).standart dokumentasi sangat penting dalam penyusunan dokumentasi asuhan keperawatan agar tidak teijadi kesalahan dalam pemberian informasi kemajuan kesehatan klien kepada petugas kesehatan lainnya

S etel ah memberikan asuhan keperawatan kepada klien dan keluarga, dokumentasi merupakan bagian yang tidak bisa di pisahkan, terutama dalam pencapaian mutu kualitas pelayanan asuhan keperawatan. Setiap pelaksanaan tugas dalam keperawatan, harus ada bukti yang tercatat dan nantinya bila ada sesuatu yang teijadi bisa ditelusuri semenjak awal dari dokumentasi keperawatan yang telah dibuat serta dapat menjadi bukti hukum apabila teijadi hal hal yang tidak diinginkan juga merupakan perlindungan hukum bagi perawat.

Ketika seorang perawat akan menuliskan 
dokumentasi yang efektif perawat harus mengikuti kaidah kaidah sebagai berikut agar dipahami oleh petugas kesehatan lainnya:

a. Simplicity: menggunakan kata-kata dasar, sederhana dan mudah dipahami. Oleh petugas kesehatan lainnya

$\mathrm{b}+\quad$ Conservatism: setiap pendokumentasian kesimpulan diagnosa keperawatan harus akurat, didasarkan pada informasi yang terkumpul baik secara subjektif atau objektif.

c. Ptience: mempergunakan waktu yang cukup untuk mengetahui apa yang teijadi pada pasien dan apa yang dilakukan pasien.

d. Irrefutability: pendokumentasian harus yang jelas dan obyektif dengan penulisan yang dapat dibaca.

Menurut Yustiana \& Abdul tahun 2016 standar dokumentasi yang lengkap menunjukkan tiga komp o nen dimana setiap komponen disertai indikator. Komponen standar dokumentasi terdiri dari

(1) Komunikasi,

(2) Akuntabilitas dan Kewajiban.

(3) Keamanan.
Standar 1: Komunikasi

Perawat melakukan dokumentasi yang berisi informasi yang akurat, relevan dan komprehensif mengenai kondisi klien, kebutuhan klien, intervensi keperawatan dan hasil kesehatan klien.

Indikator Perawat

a. Memberikan tanda tangan lengkap atau inisial, dan gelar profesional dengan semua dokumentasi;

b. Memberikan tanda tangan lengkap, dan inisial pada data base saat initialling dokumentasi; c. Memastikan bahwa dokumentasi tulisan tangan terbaca dan menggunakan tinta permanen; $d$. Menggunakan singkatan dan simbol yang masing-masing singkatan dan simbol tersebut memiliki interpretasi berbeda dan tel ah disepakati dan diterima dal am bidang pelayanan dan profesi kesehatan;

e. Mendokumentasikan saran, perawatan atau layanan yang diberikan kepada individu dal am kelompok, kelompok khusus, komunitas atau populasi (misalnya: sesi pendidikan kelompok);

f. Mendokumentasikan asuhan keperawatan yang diberikan teknologi informasi dan telekomunikasi (misalnya: 
memberikan terapi melalui telepon)

g. Mendokumentasikan inform consent ketika perawat memberikan pengobatan atau intervensi tertentu dan advokasi kebijakan dokumentasi yang jelas dan prosedur yang konsisten dengan Standar

Asuhan Keperawatan (SAK).

Seorang perawat dapat memenuhi standar dokumentasi keperawatan dengan cara:

a. Memastikan dokumentasi yang merupakan catatan lengkap tentang asuhan keperawatan tersedia dan mencerminkan semua aspek proses keperawatan, termasuk penilaian, perencanaan, intervensi (independen dan kolaboratif) dan evaluasi;

b. Mendokumentasikan informasi baik berupa data objektif maupun data subjektif;

c. Memastikan bahwa rencana perawatan jelas, terkini, relevan dan individual untuk memenuhi kebutuhan dan keinginan klien;

d. Meminimalkan duplikasi informasi dal am catatan kesehatan;

e. Mendokumentasikan komunikasi yang signifikan dengan anggota keluarga/orang lain yang signifikan, pengganti pengambil keputusan dan penyedia perawatan lainnya, f. Memastikan bahwa data informasi perawatan klien tel ah disimpan dal am dokumen hard copy sementara (seperti KARDEX, laporan shift atau buku komunikasi) serta disimpan dalam catatan kesehatan permanen. Sebagai contoh, jika si stem elektronik tidak tersedia, perawat harus memastikan bahwa informasi yang disimpan dalam dokumen sementara dimasukkan dalam si stem elektronik bila tel ah tersedia lagi.

Standar 2: Akuntabilitas dan Kewajiban

Perawat mendokumentasikan asuhan keperawatan sesuai dengan standar profesional dan etika, peraturan dan kebijakan yang relevan dari rumah sakit.

Indikator Perawat:

a. Pendokumentasian perawatan dilakukan sesegara mungkin setelah tindakan perawatan dilakukan.

b. Penulisan tanggal dan waktu pelaksanaan tindakan perawatan.

c. Dokumentasi di buat berdasarkan urutan kronologis kejadian.

d. Pendokumentasian tidak boleh meninggalkan baris kosong pada $1 \mathrm{emb}$ ar dokumentasi perawat harus menutup bagian 
yang kosong itu dengan garis yang memenuhi $1 \mathrm{emb}$ ar dokumentasi.

Bilamana dokumentasi menggunakan si stem elektronik perawat harus menahan diri sampai koreksi entri data yang keliru sambil memastikan bahwa informasi asli tetap terlihat sesuai dengan kebij akan aturan rumah sakit.

e. Mengoreksi entri data yang keliru sambil memastikan bahwa informasi asli tetap terlihat. f. Dilarang menghapus, mengubah atau memodifikasi dokumentasi orang lain

g. Dokumen apapun yang tak terduga, kejadian tak terduga atau abnormal untuk klien, harus di rekam berdasarkan fakta kejadian dengan berkaiatan dengan proses perawatan.

\section{Standar 3: Keamanan}

Perawat melindungi informasi kesehatan klien dengan menjaga kerahasiaan dan menyimpan informasi sesuai dengan prosedur yang konsisten sesuai dengan standar profesional dan etika berdasarkan peraturan perundang-undangan yang relevan. perawatan klien yang relevan diambil dal am catatan kesehatan klien, seperti yang didefinisikan oleh kebijakan rumah sakit.

b. Mempertahankan kerahasiaan informasi kesehatan klien, termasuk password atau informasi yang diperlukan untuk mengakses catatan kesehatan klien.

c. Memahami dan mematuhi kebijakan, standar dan peraturan perundang-

Indikator Perawat

a. Memastikan bahwa informasi 
undangan yang berkaitan dengan kerahasiaan, privasi dan keamanan.

d. Mengakses informasi hanya dapat dilakukan oleh perawat yang memiliki kebutuhan profesional untuk memberikan perawatan.

e. Menjaga kerahasiaan klien lain dengan menggunakan ini si al atau kode ketika mengacu pada klien lain dal am catatan kesehatan klien (misalnya, menggunakan inisial ketika mengutip teman sekamar klien)

f. Memfasilitasi hak-hak klien untuk mengakses informasi kesehatan tentang dirinya.

g. Memeriksa dan mendapatkan salinan catatan kesehatan, seperti yang didefinisikan oleh kebijakan rumah sakit.

h. Memperoleh persetujuan dari klien atau pengganti pengambil keputusan untuk menggunakan dan mengungkapkan informasi kepada orang lain di luar lingkaran perawatan, sesuai dengan peraturan yang relevan.

i. Menggunakan metode yang aman untuk mengirimkan informasi kesehatan klien (misalnya, menggunakan garis aman untuk fax atau e-mail). j. Mempertahankan catatan kesehatan sesuai dengan kebijakan dan peraturan organisasi dan melakukannya sebagai bagian dari tanggungjawab perawat.

k. Memastikan penghancuran dokumen yang sudah tidak dip erlukandengan aman dan menjaga rahasia dokumen tetap teijaga.

\section{Kesimpulan}

Standar dokumentasi adalah pernyataan tentang kualitas dan kuantitas dokumentasi dipertimbangkan secara baik untuk memperkuat pola pencatatan dan sebagai petunjuk atau pedoman pendokumentasian dal am tindakan keperawatan. Perawat memerlukan standar dokumentasi sebagai petunjuk dan arah agar tidak teijadi penyimpangan dan melakukan teknik pencatatan dengan benar, standart dokumentasi sangat penting dal am penyusunan dokumentasi asuhan keperawatan agar tidak teijadi kesalahan dal am pemberian informasi kemajuan kesehatan klien kepada petugas kesehatan lainnya 


\section{Referensi}

Departemen Kesehatan RI. (2005).

Evaluasi Penerapan Standar

Asuhan Keperawatan. Jakarta.

Departemen Kesehatan RI. (2010). Standar

Asuhan Keperawatan, Jakarta.

Dinarti dan Yuli. (2017). Dokumentasi

Keperawatan.Jakarta.Kementrian

kesehatan Republik Indonesia.

Kozier dkk. (2004). Fundamental

Keperawatan Konsep, Proses, dan

Praktik Edisi 7. Jakarta : EGC.

Kozier dkk. (2010). Fundamental

Keperawatan Konsep, Proses, dan

Praktik Edisi 7 Volume 2. Jakarta :

EGC.

Kozier dkk. (2015). Buku Ajar

Fundamental Keperawatan, Konsep,

Proses,dan Praktik Volume 7. Jakarta

: EGC.

Laura.A dkk. (1997). Pengkajian

Keperawatan Kritis Edisi 2. Jakarta :

EGC.

Rohmah, N. dan Walid, S. (2009). Proses keperawatan, teori dan aplikasi dilengkapi dengan petunjuk praktis penyususnan proses keperawatan dan dokumentasi NANDA-

NOCNIC. Jogjakarta. Arrus Media.

Simamora, R. H. (2018). Peran Manajer dalam Pembinaan Etika Perawat

Pelaksana dalam Peningkatan

Kualitas Pelayanan Asuhan

Keperawatan Jurnal IKESMA, vol.

4 No. 2

Simamora, R. H. (2009). Dokumentasi

Proses Keperawatan, jember

University press

Simamora, R. H. (2010). Komunikasi dalam Keperawatan. Jember University Press

Tarwoto dan Wartonas. (2015).

Kebutuhan Dasar Manusia dan Proses Keperawatan. Yogyakarta. Salemba medika.

Wahid, Abdul. (2012). Dokumentasi

Proses $K$ 
keperawatan. Yogyakarta,PT. Nuha Medika.

Yustiana \& Abdul. (2016). Dokumentasi

Keperawatan.Jakarta.Kementrian

kesehatan Republik Indonesia. 